\title{
ANOTHER ENGLISH CONNECTION: JOHN COWPER POWYS, WALT WHITMAN, AND PERCY IVES
}

\author{
J. Lawrence Mitchell
}

IN THE FALL of 1880, Percy L. Ives, a newly enrolled art student at the Pennsylvania Academy of Fine Arts, paid a historic visit to Walt Whitman in the home in Stevens Street, Camden, New Jersey, that Whitman shared with his brother George. Ives appears not to have read any of Whitman's poems at the time, although he had read Emerson and Carlyle, as Whitman noted in his Commonplace Book after the visit (November 17, 1880); ${ }^{1}$ it was his grandmother, Mrs. Elisa Leggett, who "suggested that I had better go across the river to Camden to see him." With a proper sense of his calling, the youthful Percy-not yet seventeen-was bold enough to ask Whitman whether he could "make a sketch" of the poet and was permitted to do so. After a two-hour session, this first effort significantly drew no critical comment from Whitman, just an open invitation: "Sometime when you come again ... you may be able to make another sketch" ("Ives" 6). The initial sketch does not appear to have survived, ${ }^{3}$ but Charles E. Feinberg reproduced two later ones, then in his collection, each dated "Dec. 6. '81": one is a head-and-shoulders portrait, labeled "Walter Whitman" and the other is a study of a left hand holding an open book, labeled "Walt's hand" ("Ives" 5). ${ }^{4}$ Though Joann P. Krieg describes these as "preliminary sketches" for the oil portrait of Whitman that Ives completed in $1882,{ }^{5}$ the differences between the drawings and the oil painting make this claim rather unlikely - especially since Ruth L. Bohan explicitly links the oil painting with a sketch made on February $12,1881 .{ }^{6}$ The portrait, described at the time as "a very strongly painted and correctly drawn portrait of Walt Whitman"7 was gifted to his grandmother who had encouraged him to visit the poet. ${ }^{8}$ For a time the painting was displayed in the storefront window of Roehm and Wright, an upscale Jewelers and Silversmiths in Detroit, perhaps also through the agency of his grandmother (Detroit 8).

Recently a long-lost third graphite (pencil) drawing from the same period, with obvious affinities to the sketch of December 6, 1881, and an impeccable provenance, has reappeared (see back cover).$^{9}$ It is on 
machine-made woven paper that measures 6.25 by 8.5 inches and is mounted on gray board. Cushing Memorial Library and Archives (Texas A\&M University) acquired the drawing directly from the Powys family in Dorset, England. ${ }^{10}$ Like the other drawings, it is signed by the artist and dated, in this case "Camden Dec. 21/1881"; unlike the others, it is also signed by Whitman himself, albeit in a rather shaky hand. No doubt this is the version that both artist and sitter deemed most satisfactory and that therefore merited Whitman's imprimatur in the form of his signature. Such explicit evidence of Whitman's approval may explain why Percy Ives kept the drawing for himself so long. In any case, we can discern in the three portrait drawings (February 12, 1881; December 6, 1881; December 21, 1881) a marked progression away from conventional portraiture, as Ives gained confidence and learned to see Whitman-perhaps with some discreet guidance from his subject-as a monumental figure, as a poet-seer.

Ed Folsom has demonstrated the significance of Whitman's many "illustrations of the self" in Leaves of Grass ${ }^{11}$ and makes a very persuasive case for Whitman's preference for photographic over other representations of the self. ${ }^{12} \mathrm{He}$ cites, for example, the comment by Whitman recorded in Horace Traubel's With Walt Whitman in Camden that photography "lets nature have its way" whereas "the botheration with the painters is that they don't want to let nature have its way: they want to make nature let them have their way." ${ }^{\prime 3}$ But he also documents Whitman's doubts, even anxiety, about the disconcerting revelatory powers of photography and thus his need to "manipulate" (a key word for Folsom) images of himself wherever possible. In particular, he points to the implicit contradiction between "a poet who celebrated the fullness and wholeness of an endlessly diverse self" and "the images that he chose to have reproduced ... that he would sanction as the authentic Whitman" (Representations 128). By the 1880s, Folsom argues, Whitman's doubts evolved into something approaching disillusionment with such celebrity photographers as Frederick Gutekunst and he "never felt the affection for any of them that he felt for the early, more rugged artisans of the craft of photography" (156). So, it would appear, the timing was just right for Whitman to take under his wing a malleable young artist such as Percy Ives whose eyes might be opened and whose sketches might come to embody the latest version of "the authentic Whitman."

The Walt Whitman Archive documents more than eighty portraitstyle representations of the poet by 1881 - Whitman was anything but camera-shy_yet Ives's compelling interpretation owes nothing to any of these. Given his cultivation of a number of young artists who drew and/or painted him-Herbert Gilchrist had preceded Percy Ives, for example ${ }^{14}$ - it is not implausible that Whitman was seeking far more control over how he was represented to the world, another form of what 
Bohan calls "visual self-fashioning." 15 In any case, Whitman is no longer seen by Ives as the "rough sort of person" he had originally envisaged meeting, ${ }^{16}$ or even as the ordinary mortal with a furrowed brow depicted in the earlier sketch of February 12, 1881 (Bohan 73, Fig. 31). In the drawing of December 21, the poet has become something quite different: a radiant, almost godlike, figure with impressively strong and sculpted features. We are a long way from the studied spontaneity of the Harrison-Hollyer frontispiece steel engraving in the 1855 edition of Leaves of Grass. If, as Folsom has argued, Whitman was "always a careful critic of his own image," what version of himself does this portrait embody and endorse? ("Illustrations" 136). It is certainly hard to discern anything of the demotic or the 'democratic' in it. However, we do have Percy Ives's retrospective account of how he responded to Whitman: "Art always has been associated, when it has been at its best and its purest, with religion - and it is upon the prophetic and the religious side that Walt Whitman appeals to the artist" ("Artist Poet!" 16, col. 1).

The existence of such a drawing was not totally unknown; ${ }^{17}$ it had been reproduced in Bohan's Looking into Walt Whitman from the glass negative in the Feinberg-Whitman Collection (Library of Congress) some years before the rediscovery of the original drawing. ${ }^{18}$ But its fate and its role as a simulacrum for the good gray poet were quite unknown until now. There can be no doubt that the drawing itself dates from 1881 - despite what looks like an 1887 in the lower right corner ${ }^{19}$ - because Ives wrote to his grandmother on December 26, 1881: "I was with him on the $21^{\text {st }}$ Dec. and had a fine long visit, made two pencil sketches of him." ${ }^{20}$ Moreover, in 1887 Ives was still at the Academy Julian in Paris enjoying - on the evidence of his diary - a protracted flirtation with Olga and Louise, two of his models. ${ }^{21}$ And there are surviving letters of Percy's to Whitman from Paris (1886) and London (1887) that testify to his whereabouts.

Enter John Cowper Powys -the eldest in the large and talented family of a Church of England vicar, the Reverend Charles Francis Powys, of Montacute, Somerset. With a degree from Cambridge University in 1894, the son became a University Extension lecturer, at first in England, and, from 1905, in the United States. He was a charismatic and unabashedly histrionic lecturer on literary and other topics who used to say that he learned to lecture from watching Henry Irving act. As Kenneth Hopkins recalled, "his tall figure and striking, hawk-like head made his hold on an audience complete from the moment he stepped on to the platform." 22 For some thirty years he crisscrossed America indefatigably - the newspapers of Atlanta, Boston, Chicago, Dallas, Minneapolis, New York, Philadelphia, and San Francisco bearing witness to his popularity. He seems to have "discovered" Whitman by 1907, 
and in September 1909, from his home in Burpham in Sussex, he wrote of "my dearest and longest cherished of all literary projects, namely the composing of a book of poems more or less in the style of old Walt." 23 During a 1910 lecture tour in Philadelphia he recalled: "In some cases I would improvise poetry - in the style of Walt Whitman - (how often have I written that last sentence!)" (Letters 87). His 1912 address to the Socialist Literary Society in Philadelphia made headlines in The New York Times because "Powys of London" criticized the Concord School of American writers, declaring recklessly that "Emerson, Lowell, Hawthorne, Longfellow, and Holmes would be forgotten for centuries when the memories of Walt Whitman and Edgar Allan Poe are still fresh." 24

At the time, Powys was the author of but two slender volumes of poetry more in the manner of Hardy than of Whitman; but in February 1915, he published Visions and Revisions, ${ }^{25}$ a book of essays culled from the lectures he had just completed "at top speed" while comfortably ensconced in a Chicago studio overlooking Lake Michigan. Powys used to claim-perhaps with tongue in cheek - that Thomas Hardy kept a copy of this book at his bedside. It is better documented that his friend Isadora Duncan, the free-spirited "mother of modern dance," sent him roses upon the book's publication. ${ }^{26}$ It sold well and was in its third printing by the time Powys arrived in Detroit in early October 1915 to begin a series of lectures in McCollester Hall. ${ }^{27}$ It was by no means his first visit to Detroit; his 1911 lecture tour had been widely acclaimed. The Detroit Free Press was kind enough to grant him an "honorary" doctorate at the time, reporting that " $D r$. John Cowper Powys probably aroused more enthusiasm last Saturday in his lecture on [Sir Walter] Scott than any other lecturer who has come to Detroit for a long time. Dr. Powys is like no one else; he has a little brogue, a remarkable magnetic power with his audience, and thoughts that are peculiarly his own." 28

Crucially, Visions and Revisions contained a brief, but laudatory, essay on Whitman that begins: "I want to approach this great Soothsayer from the angle least of all profaned by popular verdicts. I mean from the angle of his poetry." ${ }^{29}$ He compares Whitman favorably with the "fourth-hand Protestantism that Browning dishes up" (poor Browning was often his target) and then proclaims:

Walt Whitman, more than anyone, is able to convey to us that sense of the unclassified pell-mell, of weeds and stones and rubble and wreckage, of vast desolate places, and spaces full of debris and litter, which is most of all characteristic of your melancholy American landscape. . . No one like Whitman can convey to us the magical ugliness of certain aspects of Nature-the bleak, stunted, God-forsaken things; the murky pools where the grey leaves fall; the dead reeds where the wind whistles no sweet fairy tunes; the unspeakable margins of murderous floods; the tangled sea-drift, scurfed 
with scum; the black sea-winrow of broken shells and dead fishes' scales. . . [T] hese are the things, the ugly, terrible things, that this great optimist turns into poetry. (281)

If the by then aging Percy Ives had read this encomium, he would at once have recognized in Powys a kindred spirit to Whitman; if he had also been in the audience during one of the Englishman's lectures he would surely have introduced himself to this fellow devotee. We don't, in fact, know exactly how or specifically where they met; all we know for sure is that Ives gave his precious 1881 drawing to Powys, inscribing it: "Detroit Nov. $3^{\text {rd }}$ 1915. A souvenir of appreciation / to John Cowper Powys / from Percy Ives."

There is, alas, no record of what Powys actually said about Whitman during his 1915 visit to Detroit, though it would surely have been in the same enthusiastic vein as his published essay. Occasionally though, a reference to Whitman slips into letters home from his many stoppingpoints: "I've seen lots of things that Walt Whitman mentions-moss hanging down from a live-oak in Louisiana-for instance," he writes from San Francisco to his sister in April 1917.30 The next month he arrived in Portland, Oregon, for the first time, and the local paper, The Oregonian, reported his opening lecture in rapturous detail under the headlines: "FINE TRIBUTE PAID / John Cowper Powys Lauds Walt Whitman." He had already delivered a luncheon lecture on "The Relationship Between Literature and Sociology" at the Hotel Multnomah. There the audience was "stirred as but seldom in their lives" and, at the close of the talk, "sat in awed silence and those who heard the lecture were still spellbound when they walked slowly from the room." The much-anticipated evening lecture on Whitman was to be the first in a series of four at the Civic Club:

The reward of Whitman was tardy said the distinguished lecturer . . . as always with great natural poets there is "a long interval of hesitation before their own people know them for what they are." Yet noted Englishmen of letters had long since adopted Whitman as the friends of their hearts. . . For two years I was under this man's spell, dominated by this character, as, indeed, I have never been dominated by any other. It was only since I have shaken myself free that I have been able to interpret Walt Whitman. ${ }^{31}$

As a rare record of what Powys actually said about Whitman in one of his lectures, this newspaper account is obviously invaluable. Of course, there is no doubt that he included himself among "the noted Englishmen of letters" who appreciated Whitman. Sometimes, however, local newspapers provide little more than the title of Powys' talk. The Chicago Tribune, for example, informed the readers of its Women's Club Page in January 1920 that "John Cowper Powys of Oxford University [sic] will 
speak on Walt Whitman's 'The Poetry of Comradeship' tomorrow night at Sinai Social Center." 32 And, on occasion, we may encounter a fragment of Whitman family gossip picked up on Powys' travels and relayed back home to his sister in Somerset, as in this revealing observation:

I've just come from Memphis, Tennassee [sic] where I lectured on Walt Whitman to these damned slave-dealing cotton-merchants. Do you know I met in Memphis a grand-niece of Walt Whitman's who up to seven years old had actually lived on the old Whitman and Van Velsor farm at West Hill Long Island . . . . And the woman had a daughter who actually resembled Walt Whitman very strikingly. She had been brought up to be ashamed of him. (Head 38)

John Cowper Powys was not the only member of his family to fall for the poetry and the persona of Walt Whitman. Sometime in 1909 he introduced his sister, usually called "Katie" or Philippa, to Whitman's work, and thereafter he regaled her with tidbits of Whitman trivia (as above) - once even sending "some grass blades (leaves of grass)" from a pilgrimage of sorts he made with his American publisher Max Schuster to Paumanok (Head 73). His sister responded by clinging with "an almost mystical devotion to [Whitman] throughout her life, rarely travelling without a copy of Leaves of Grass"-which she dubbed "my Bible" (14). Her brother John was in Chicago when she arrived in New York late in 1923 for her only visit to America, but he welcomed her from afar with a few lines - obviously recalled rather than copied-from "Starting From Paumanok":

Well, you are near enough to 'Paumanok' now; and the 'sediment' that stands for all the wind-rows on the shores of all the beaches of the earth!-Mêlange, my own, the seen $\&$ the unseen; mysterious ocean where the streams empty! (49)

Inevitably, during her four-month trip to America (November 1923-April 1924), she simply had to visit her hero's home in Camden. In what Anthony Head generously calls "an act of devotional vandalism," Katie / Philippa supposedly carved her initials on the chair in Whitman's study (16). It was subsequent to this memorable visit that John gave his sister the drawing of Whitman that Percy Ives had given him in 1915. On the back of the by then oak-framed portrait he wrote in ink:

Philippa Powys / from / John Cowper Powys / This was drawn in that house / you went into a year I think / before Walt Whitman died and /the artist, then a boy-pet of / Walt Whitman's, gave it to me when / - he told me he got Walt Whitman / to sign it - he himself / was a fairly old man.

From this somewhat convoluted inscription ("a year I think before Walt Whitman died" is obviously intended to modify "This was drawn"), 
we can tell that Powys - mistakenly but understandably — read the date of composition as 1887. His confident designation of the artist as "a boy-pet" of Whitman's suggests a mistaken understanding of the relationship between Whitman and Ives; but it may also be read as covert acknowledgement of his sister's androgynous inclinations. ${ }^{33}$

Some thirty years later, John Cowper Powys had long retired from the busy world of lecturing to Corwen in North Wales so that he could devote himself to his own novels. Yet Whitman's Leaves of Grass still served as a kind of vade mecum - in Powys' case, it was the 1902 Thomas Crowell edition, with an introduction by John Burroughs. In 1957, he recalled that Whitman was one of the only two authors he "ever carried about in my pocket wherever I went." The other was William Hazlitt. Nonetheless, he often relied upon memory when quoting Whitman and thus offered a slightly garbled version of the "death passage," as he called it, in response to some inquiry from his sister:

Come lovely and soothing

death undulate

round the world

sweetly arriving

sooner or later

delicate death.

But the old lecturing habits were not forgotten, and he adds: "it seems to me that in some long-island poem about the sea he makes the wildest $\&$ roughest sea able to be 'delicate' too-so to him both Death and the sea could be delicate when they wanted to be" (Head 246). The two, brother and sister, were increasingly aware of their own mortality-during 1952-1953 they had a lost a sister (the artist, Gertrude) and a brother (the novelist, Theodore) - so Whitman's "delicate" death clearly afforded some real consolation.

Texas AEM University

\section{NOTES}

1 Cited in Charles E. Feinberg, "Percy Ives, Detroit and Walt Whitman," Detroit Historical Society Bulletin 16 (February 1960), 5; hereafter, "Ives." The manuscript Commonplace Book is part of the Charles E. Feinberg Collection, now in the Library of Congress. The text is reproduced in Whitman, Daybooks and Notebooks, ed. William White (New York: New York University Press, 1978), 1:210.

2 "Artist Poet! Reminiscences of Walt Whitman," Detroit Sunday News-Tribune (April 5, 1896), 5; cited in Feinberg (1960); hereafter, "Artist Poet!" 
3 It might just be the undated and unsigned profile sketch in "Artist Poet!" This rather conventional rendition is attributed to Percy Ives in the article, but has been overlooked or at least has stimulated no critical interest.

4 Despite the clearly visible dates on the drawings themselves, the caption erroneously reads "Two sketches made by Percy Ives when visiting Whitman in 1880."

5 Joann P. Krieg, "Percy Ives, Thomas Eakins, and Whitman," Walt Whitman Quarterly Review 15(Summer 1997), 27.

6 Ruth L. Bohan, Looking into Walt Whitman: American Art, 1850-1920 (University Park: Pennsylvania State University Press, 2006), 73, Figure 31; hereafter, Looking into $W W$. She includes reproductions of four drawings and two oil portraits by Percy Ives (73-75).

7 Detroit Free Press (September 27, 1883), 8; hereafter, Detroit.

8 The portrait (Bohan, Looking into $W W, 73$, Figure 30) was subsequently purchased by Feinberg from Elisa Leggett's estate and is now in the Library of Congress (LCUSZC4-11462).

9 It has now been professionally treated by a paper conservator, deacidified, and framed behind museum glass. The halo-like line (from moisture) round Whitman's head was already present when the glass negative was made.

10 While in England for a conference, I was approached by a member of the Powys Family circle about the possibility of finding a "good home" in America for the drawing.

11 "The portraits were as essential a part of the book as the poetry was," writes Ed Folsom, "Illustrations of the Self in Leaves of Grass," in Ezra Greenspan, ed., The Cambridge Companion to Walt Whitman (Cambridge University Press, 1995), 138; hereafter, "Illustrations."

12 See especially Chapter 4 ("Whitman and Photography") and Chapter 5 ("Whitman and Photographs of the Self") in Ed Folsom, Walt Whitman's Native Representations (Cambridge University Press, 1994); hereafter, Representations.

13 Horace Traubel, With Walt Whitman in Camden, Vol. 4, ed. Sculley Bradley (Philadelphia: University of Pennsylvania Press, 1953), 125; cited in Folsom, Representations, 102.

14 For further information on this, see Bohan, Looking into WW, 59-69.

15 Bohan, Looking into WW, Chapter 3, "Visual Self-Fashioning and Artistic (Re-) Assessment," provides a detailed account of Whitman's relationships with artists and "casts doubt on the claim that Whitman consistently preferred photography to more traditional visual media" (68). The fact that Sidney Morse destroyed his bust of Whitman because the poet disliked it can thus be productively read against the fact that Whitman signed the December 21 drawing by Percy Ives.

16 The phrase used by Ives in his Detroit Sunday News-Tribune interview after Whitman's death; quoted in Feinberg, "Ives," 5.

17 There is no mention of the Ives drawing in the impressively comprehensive-but privately printed-Whitman Portraits (Toronto, 1922), compiled by Henry S. Saunders.

18 It is Figure 33 in Bohan, Looking into $W W, 74$, and is listed as LC-X12-1 in the Feinberg-Whitman Collection, Library of Congress. 
19 The Library of Congress catalog and the finding guide both date it erroneously as 1887. For the reproduction from the glass negative, see Digital ID: ds 03395 hdl. loc.gov/loc.pnp/ds.03395 in the Library of Congress.

20 Leggett Family Papers, Burton Historical Collection, Detroit Public Library; cited in Feinberg, "Ives," 7.

21 Archives of American Art, Smithsonian Institution, Percy Ives Papers, Diary 1885-1887; Microfilm reel 593 of records in Burton Historical Collection, Detroit Public Library.

22 Kenneth Hopkins, The Powys Brothers: A Biographical Appreciation (Rutherford, New Jersey: Fairleigh Dickinson University Press, 1967), 27.

23 Malcolm Elwin, ed., Letters to His Brother Llewelyn, Vol. 1 1902-1925 (London: Village Press, 1975), 54; hereafter Letters.

24 “Criticises Concord Writers," The New York Times (February 6, 1912).

25 Powys' book was included in the bibliography of Harold W. Blodgett's Whitman in England (Ithaca: Cornell University Press, 1934), but his enthusiastic - and very public - support for Whitman is nowhere mentioned, because Blodgett restricts himself to Whitman's lifetime.

26 In 1915, Isadora Duncan was performing at the Century Theater in New York. In a letter to his brother Llewelyn, two years later (November 18, 1917), Powys recalled: "she sent me so many red roses that they filled the little flat, but I was too nervous to go and see her."

27 See the Detroit Free Press (October 5, 10, 24, 1915).

28 Detroit Free Press (November 12, 1911).

29 John Cowper Powys, Visions and Revisions (New York: G. Arnold Shaw, 1915), 281; hereafter, Visions.

30 Anthony Head, Powys To Sea Eagle: The Letters of fohn Cowper Powys to Philippa Powys (London: Cecil Woolf, 1996), 37; hereafter, Powys to Sea Eagle.

31 The Oregonian (May 6, 1917).

32 Chicago Tribune (January 25, 1920), E5, col. 7.

33 She became infatuated with Stephen Reynolds in 1909, author of A Poor Man's House (1908), who used to read to her from Whitman. In later years, her affections were typically directed towards women-first Valentine Ackland and then Elizabeth Wade White (see letters from Katie to EWW, spanning 1938 through 1954, in the New York Public Library). 